\title{
Simulasi Arahan Penggunaan Lahan di DAS Limboto dalam Rangka
}

\section{Pengendalian Kekeringan}

\section{Sri Rahayu Ayuba ${ }^{1}$, Munajat Nursaputra $^{2}$ dan Intan Noviantari Manyoe ${ }^{3}$}

${ }^{1}$ Faculty of Sains \& Technology, Muhammadiyah University of Gorontalo, Indonesia. ${ }^{2}$ Faculty of Forestry, Hasanuddin University, Indonesia dan ${ }^{3}$ Faculty of Math and Science, State University of Gorontalo.

*Email Koresponden : srirahayu@umgo.ac.id

Direvisi: 2018-01-25. Diterima: 2019- 08-21

(02019 Fakultas Geografi UGM dan Ikatan Geograf Indonesia (IGI)

\begin{abstract}
Abstrak Berdasarkan data BNPB tahun 1979-2009 terdapat 8 kejadian kekeringan di Provinsi Gorontalo. Penelitian ini bertujuan untuk mengetahui tingkat kerentanan DAS Limboto terhadap kekeringan, serta menyusun dan mengsimulasikan arahan penggunaan lahan untuk pengendalian kekeringan. Penelitian ini dilaksanakan pada Daerah Aliran Sungai (DAS) Limboto dengan luas area 86412,6 ha. Metode yang digunakan adalah SWAT (Soil and Water Assessment Tool). Input data SWAT yang digunakan adalah lereng, jenis tanah, tutupan lahan, dan iklim. Analisis output ArcSWAT (Soil Water) diklasifikasikan dalam index SMDI klasifikasi menurut Narasimhan dan Srinivasan. Dari penelitian ini menunjukkan pasokan air pada DAS Limboto secara keseluruhan berada pada indeks -3,00 sd -3,99 atau termasuk dalam kategori "Rentan". Persentase lahan yang masih bervegetasi adalah $>50 \%$ sehingga tidak dilakukan perubahan pada lahan terbangun. Luas area yang mengalami kekeringan pada sebelum dan setelah simulasi/running diperoleh selisih $37.513,1$ ha atau secara persentasi mengalami penurunan sebesar $43,4 \%$ dari luas DAS.
\end{abstract}

Kata kunci: Arahan Penggunaan Lahan; Kekeringan; Daerah Aliran Sungai Limboto; Simulasi Arahan.

Abstract Based on BNPB data from 1979 to 2009 there were 8 drought events in Gorontalo Province. This study aims to determine the vulnerability of the Limboto watershed to drought, and to compile and simulate land use directions for drought control. This research was carried out in the Limboto Watershed with an area of 86412.6 ha. The method used is SWAT (Soil and Water Assessment Tool). Input of SWAT data used is slope, soil type, land cover, and climate. Analysis of the output of ArcSWAT (Soil Water) is classified in the index SMDI classification according to Narasimhan and Srinivasan. From this study, the overall water supply in the Limboto watershed is in the index of -3.00 to -3.99 or included in the category "Vulnerable". The percentage of land that is still vegetated is $>50 \%$ so no changes are made to the built up land. The area that experienced drought before and after the simulation / running obtained a difference of 37,513.1 ha or percentage decreased by $43.4 \%$ of the watershed area.

Key words: Land Use Referrals; Drought; Limboto Watershed; Landing Simulation..

\section{PENDAHULUAN}

Air merupakan inti dari pembangunan berkelanjutan. DAS berfungsi sebagai pengatur sumber daya air yang sangat penting (Tarigan \& Junaidi, 2015). Kurangnya pasokan air yang berkepanjangan menyebabkan turunnya muka air tanah, sungai, dan danau serta berkurangnya kelengasan tanah yang mengakibatkan tumbuhan menjadi layu sehingga produksi pangan akan menurun (Meilianda, 2017). Laporan kajian kekeringan global, IPCC (2007), berdasarkan Palmer Drought Severity Index (PDSI) mengindikasikan adanya peningkatan intensitas kekeringan beberapa dasawarsa terakhir (Meilianda, 2017). Merujuk pada keputusan Menteri Kehutanan tahun 2009, Daerah Aliran Sungai (DAS) Limboto Bone Bolango, ditetapkan sebagai DAS dalam kondisi kritis dan memerlukan prioritas penanganan. (Kodoatie,
2010) menyatakan bahwa, terganggunya siklus hidrologi telah menimbulkan "3 T" masalah klasik air "too much (yang menimbulkan banjir), "too little (yang menimbulkan kekeringan) dan "too dirty (yang menimbulkan pencemaran air).

Berdasarkan data BNPB tahun 1979-2009 terdapat 8 kejadian kekeringan di Provinsi Gorontalo. Kepala Badan Penanggulangan Bencana Daerah (BPBD) Kabupaten Gorontalo menyatakan bahwa kekeringan sebelumnya terjadi hanya di 11 kecamatan, namun pada bulan Oktober tahun 2015 menjadi 19 kecamatan. Fenomena pemanfaatan lahan untuk kegiatan pertanian ini telah menjadi kegiatan utama yang dilakukan oleh masyarakat sejak dicanangkannya program agropolitan di Provinsi Gorontalo. Pengelolaan DAS yang 
salah satunya adalah penyusunan arahan fungsi pemanfaatan lahan harus dilakukan secara terpadu dan disepakati oleh para pihak (stake holders) sebagai dasar dalam penyusunan rencana pembangunan wilayah (Wuryanta, 2015). Dalam DAS diperlukan perencanaan yang matang guna mencegah segala kemungkinan terburuk, salah satunya adalah dengan pembuatan model perencanaan penggunaan lahan dalam rangka pengendalian kekeringan. Model SWAT mampu mensimulasikan parameter-parameter hidrologi dalam jangka panjang dengan mempertimbangkan karakteristik fisik suatu DAS. Dengan demikian diharapkan DAS Limboto akan mampu mengendalikan berbagai masalah yang ada terutama masalah kekeringan.

\section{METODE PENELITIAN}

Penelitian ini menggunakan metode SWAT melalui penggunaan aplikasi ArcSwat. Saat ini model SWAT telah berkembang dengan pesat dengan aplikasi yang sangat beragam mulai dari simulasi hidrologi yang sangat sederhana, simulasi dampak perubahan tata guna lahan, simulasi dampak perubahan iklim bahkan sampai dengan simulasi untuk memprediksikan produktifitas suatu lahan pertanian (Ferijal, 2013). Teknik analisis dalam penelitian ini dikelompokkan dalam 2 tahap analisis, pertama analisis model SWAT menggunakan software ArcSwat dan kedua analisis output model SWAT dalam menentukan kerentanan DAS terhadap kekeringan dengan memanfaatkan ArcGis.

Indeks kekeringan merupakan suatu perangkat utama untuk mendeteksi, memantau, dan mengevaluasi kejadian kekeringan (Sandi Cahyono, Imam Suprayogi, 2016). Analisis yang digunakan dalam menentukan kerentanan DAS terhadap kekeringan adalah dengan menggunakan Soil Moisture Deficit Index (SMDI). Dengan menggunakan data output hasil model SWAT yakni Soil Water/SW (Kadar Air Tanah). Nilai SW kemudian diolah dalam ArcGis untuk mendapatkan nilai SMDI yang kemudian akan diklasifikasikan dalam klasifikasi SMDI. Adapun formula yang digunakan adalah: Jika, SW $\leq$ MSW

Maka,

$$
S D=\frac{S W-M S W}{M S W-\min S W} x 100
$$

Dan jika, SW > MSW

Maka,

$$
S D=\frac{S W-M S W}{\max S W-M S W} \times 100
$$

Dimana:

SD : Defisit kadar air dalam tanah (\%)

SW: Total kadar air dalam tanah pada tahun analisis

MSW: Nilai median dari total kadar air dalam tanah pada periode tahun analisis
Max SW : Nilai maksimum dari total kadar air dalam tanah pada periode tahun analisis

Min SW : Nilai minimum dari total kadar air dalam tanah pada periode tahun analisis

Nilai defisit kadar air dalam tanah (SD) tersebut kemudian dikalkulasikan dalam nilai indeks yakni Soil Moisture Deficit Index (SMDI), menggunakan rumus:

$$
S M D I_{i}=0,5 S M D I_{i-1}+\frac{S D}{50}
$$

Adapun klasifikasi indeks tersebut kemudian dikategorikan seperti pada Tabel 1 .

Tabel 1. Pembobotan Klasifikasi Indeks SMDI

\begin{tabular}{rllc}
\hline Nilai Indeks & Kategori & $\begin{array}{l}\text { Tingkat Keren- } \\
\text { tanan }\end{array}$ & Bobot \\
\hline$\geq 4,00$ & Sangat Basah & Tidak Rentan & 1 \\
3,00 sd 3,99 & Basah & Tidak Rentan & 1 \\
2,00 sd 2,99 & Agak Basah & Tidak Rentan & 1 \\
0,50 sd 1,99 & Sedikit Basah & Tidak Rentan & 1 \\
0,49 sd -0,49 & Normal & Tidak Rentan & 1 \\
$-0,50$ sd $-1,99$ & Sedikit Kering & Sedikit Rentan & 2 \\
$-2,00$ sd -2,99 & Agak Kering & Agak Rentan & 3 \\
$-3,00$ sd -3,99 & Kering & Rentan & 3 \\
$\leq-4,00$ & Sangat Kering & Sangat Rentan & 3 \\
\hline
\end{tabular}

Sumber: (Narasimhan \& Srinivasan, 2005) dalam modifikasi

\section{Perumusan Arahan Penggunaan Lahan}

Pedoman yang digunakan peneliti dalam mengarahkan penggunaan lahan adalah UU No 37 tentang Konservasi Tanah dan Air yang selaras dengan Peraturan Pemerintah Republik Indonesia Nomor 37 Tahun 2012 tentang Pengelolaan Daerah Aliran Sungai serta pola ruang kabupaten terkait. Arahan yang akan dibuat kemudian akan menghasilkan asumsi mempertahankan perencanaan daerah atau merevisinya.

\section{Simulasi Arahan Penggunaan Lahan}

Penetuan subDAS/ DAS kecil yang akan diarahkan adalah berdasarkan tingkat kerentanan yang diperoleh, yakni dengan perolehan bobot 3 , namun arahan penggunaan lahan dilakukan pada seluruh DAS Limboto. Proses ini kembali dilakukan dengan menginput data penggunaan lahan yang kemudian dirunning/simulasi kembali. Hasil running kedua ini kemudian dihitung kembali (persamaan 1-3 dan tabel 1) untuk memperoleh tingkat kerentanan DAS terhadap kekeringan.

\section{HASIL DAN PEMBAHASAN}

Penggunaan Metode SWAT melalui ArcSwat dilakukan 
untuk memperoleh tingkat kerentanan DAS Limboto terhadap kekeringan. Berbagai output dalam metode ini kemudian diolah dengan berbagai klasifikasi terkait kekeringan pada masing-masing sub DAS/ DAS Kecil. Proses running pada tahap analisis SWAT dilakukan dengan menggunakan software ArcSwat memanfaatkan menu SWAT Simulation. Tahap analisis ini dapat dilakukan apabila tahap Watershed Deliniation, HRU analysis dan Write Input Tabels telah selesai dengan baik. Data yang disimulasi adalah 10 Tahun yakni dari 1 Januari Tahun 2004 hingga 31 Desember 2013 yang mengikuti format data iklim.

Output dari proses running kemudian dianalisis berdasarkan parameter yang menunjukkan tingkat kerentanan DAS terhadap kekeringan. Adapun tahap analisis dalam penelitian ini diuraikan dalam 2 sub BAB yakni:

\section{Analisis Model Soil and Water Asessment Tools (SWAT)} Menggunakan Software ArcSwat.

Penggunaan Metode SWAT melalui ArcSwat diuraikan dalam beberapa tahapan input data berdasarkan klasifikasi SWAT. Pada tahap pertama, dilakukan delineasi daerah aliran sungai berdasarkan data Digital Elevation Model (DEM) wilayah DAS yang diteliti. Data DEM yang digunakan pada penelitian ini adalah data ASTER Global DEM dengan resolusi 30 meter. Data kelerengan merupakan data awal yang digunakan dalam tahapan delinease batas DAS. Sehingga parameter yang digunakan adalah parameter DAS dan sub DAS yang dihitung oleh SWAT. Proses delineasi batas DAS dilakukan berdasarkan outlet utama dari ketiga DAS dan outlet masing-masing DAS.

\section{Tutupan Lahan DAS Limboto}

Data tutupan lahan diperoleh dari BPKH Tahun 2013 yang kemudian di-update dengan menginterpretasi data citra satelit Landsat Tahun 2015. Penggunaan data dengan format rester menjadi salah satu syarat dalam meng-input data tutupan lahan hasil interpretasi. Data ini kemudian diklasifikasikan dalam input model SWAT, yang diuraikan dalam Tabel 2.

Berdasarkan peta Land System yang diperoleh dari RePPPort, Daerah Aliran Sungai (DAS) Limboto mempunyai jenis tanah seperti yang diuraikan dalam Tabel 3.

HRU merupakan unit terkecil dalam skala analisis yang dilakukan pada pemodelan SWAT. Unit respon hidrologi adalah bagian dari subbasin yang memiliki atribut penggunaan / pengelolaan / tanah yang unik (Arnold et al., 2011). Setelah proses delineasi, dilakukan pembentukan HRU (Hydrological Response Unit) dilakukan pada masingmasing DAS. Hal ini bertujuan untuk mendapatkan analisis sub DAS yang digunakan dalam proses running. HRU adalah tahap overlay dari beberapa data, antara lain data DEM, data penggunaan lahan, dan data tanah. Hasil pembentukan HRU mempunyai informasi mengenai penggunaan lahan, tanah, kemiringan lahan, luas area, dan presentasi luas HRU pada sub DAS. DAS
Limboto dalam penelitian ini, memperoleh $1701 \mathrm{HRU}, 49$ sub DAS dengan total luas area 86412 ha. Peta hasil pembentukan HRU DAS Limboto disajikan pada Gambar 1.

Tabel 2. Klasifikasi Tutupan Lahan DAS Limboto

\begin{tabular}{lrc}
\hline \multicolumn{1}{c}{ Tutupan Lahan } & \multicolumn{1}{c}{$\begin{array}{l}\text { Luas } \\
(\mathrm{Ha})\end{array}$} & \multicolumn{1}{c}{$\begin{array}{l}\text { Luas } \\
(\%)\end{array}$} \\
\hline FRST (Hutan Lahan Kering Primer dan & $8.550,6$ & 9,895 \\
Sekunder) & & \\
ORCD (Perkebunan) & 280,5 & 0,325 \\
URBN (Permukiman) & $2.614,5$ & 3,026 \\
AGRL (Pertanian Lahan Kering dan & $51.309,8$ & 59,37 \\
Campur Semak) & $8.903,8$ & 10.30 \\
RICE (Sawah) & $11.793,6$ & 13.64 \\
RNGB (Semak Belukar) & 27.1 & 0.031 \\
OAK (Tanah Tebuka) & $1.407,1$ & 1.628 \\
WATR (Tubuh Air) & $1.479,7$ & 1.712 \\
WETL (Semak Belukar Rawa) & & \\
\hline
\end{tabular}

Sumber: Hasil Penelitian

Tabel 3. Jenis Tanah DAS Limboto

\begin{tabular}{|c|c|c|c|}
\hline Soil_Great & ID Soil & $\begin{array}{c}\text { Luas } \\
(\%)\end{array}$ & $\begin{array}{l}\text { Luas } \\
\text { (ha) }\end{array}$ \\
\hline $\begin{array}{l}\text { Dystrpepts; Humitropepts; } \\
\text { Tropohumults }\end{array}$ & Soil 06 & 10,50 & 9069,6 \\
\hline $\begin{array}{l}\text { Dystropepts; Tropudalfs; } \\
\text { Haplorthox }\end{array}$ & Soil 09 & 2,93 & 2534,2 \\
\hline $\begin{array}{l}\text { Dystropepts; Tropudalfs; } \\
\text { Tropudults }\end{array}$ & Soil 10 & 4,98 & 4303,7 \\
\hline $\begin{array}{l}\text { Dystropepts; Tropudults; } \\
\text { Paleudults }\end{array}$ & Soil 13 & 0,24 & 203,6 \\
\hline $\begin{array}{l}\text { Dystropepts; Tropudults; } \\
\text { Troperthents }\end{array}$ & Soil 14 & 36,23 & 31305,4 \\
\hline $\begin{array}{l}\text { Dystropepts; Tropudults; } \\
\text { Tropudalfs }\end{array}$ & Soil 15 & 4,69 & 4049,7 \\
\hline Eutropepts & Soil 18 & 4,31 & 3728,6 \\
\hline Eutropepts; Tropudalfs & Soil 21 & 3,72 & 3212,6 \\
\hline Rendolls; Eutropepts & Soil 32 & 9,07 & 7839,3 \\
\hline Tropaquepts; Fluvaquents & Soil 36 & 14,11 & 12196,8 \\
\hline Tropaquepts; Tropofluvents & Soil 39 & 0,77 & 669 \\
\hline $\begin{array}{l}\text { Tropaquepts; Tropofluvents; } \\
\text { Fluvaquents }\end{array}$ & Soil 40 & 1,88 & 1625,7 \\
\hline $\begin{array}{l}\text { Tropudalfs; Tropudults; } \\
\text { Dystropepts }\end{array}$ & Soil 48 & 1,12 & 966 \\
\hline $\begin{array}{l}\text { Tropudults; Tropudalfs; } \\
\text { Eutropepts }\end{array}$ & Soil 59 & 2,09 & 1807,9 \\
\hline Soil_Great & ID Soil & $\begin{array}{l}\text { Luas } \\
(\%)\end{array}$ & $\begin{array}{l}\text { Luas } \\
\text { (ha) }\end{array}$ \\
\hline Water & WATR & 3,36 & 2900,4 \\
\hline
\end{tabular}

Sumber: Peta RePPPort dan Hasil Penelitian

\section{Data Iklim dan Proses Running}

Pada penelitian ini, pemasukan data iklim dilakukan untuk mendapatkan keluaran berupa data bulanan hasil simulasi. Data iklim dalam Simulasi SWAT terdiri dari data curah hujan dan suhu pada stasiun yang mewakili daerah DAS, 


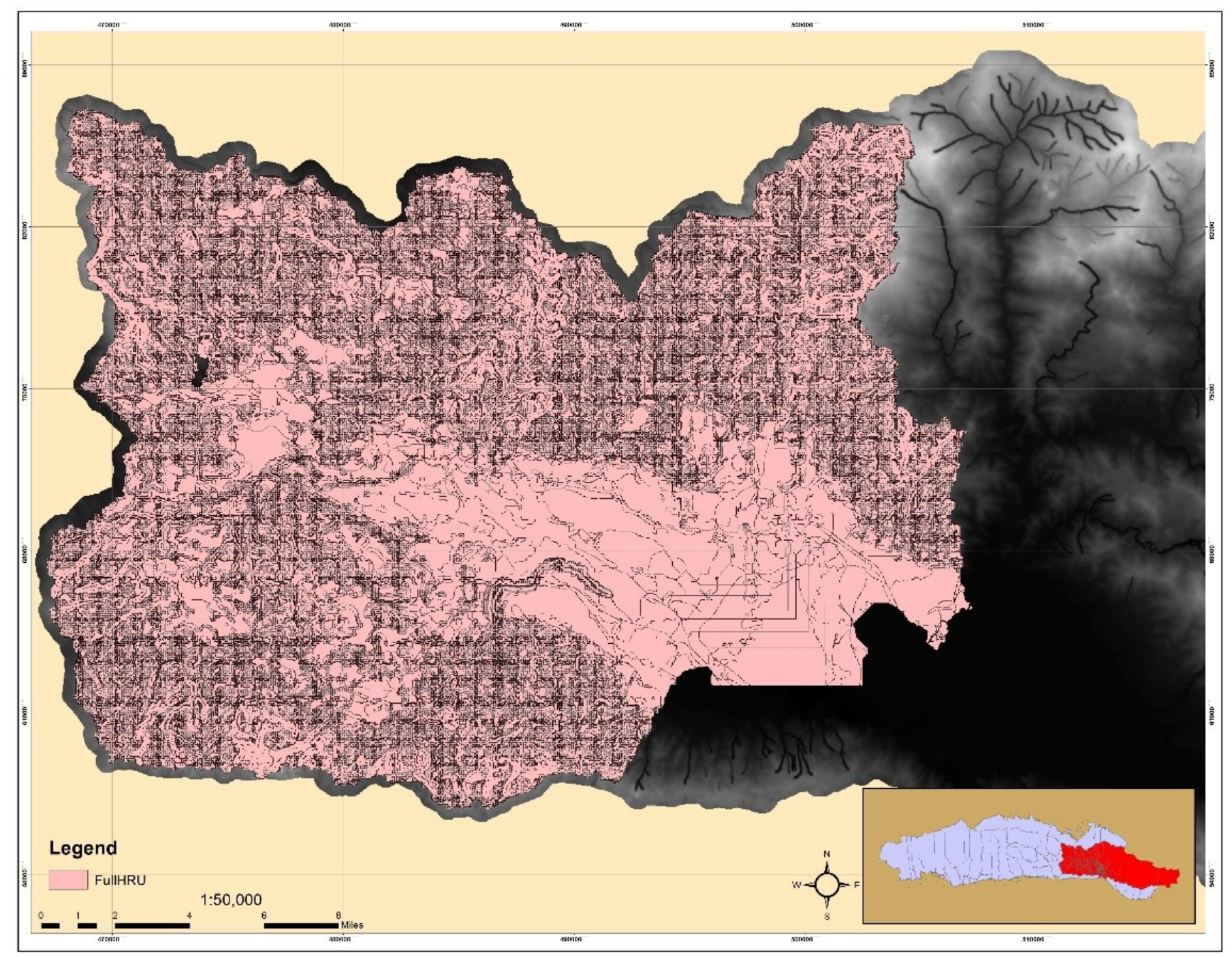

Gambar 1. Peta HRUs DAS Limboto

serta data Weather Generator berupa radiasi matahari, kecepatan angin, suhu, curah hujan, dan titik embun. Setelah Penginputan data iklim, dilanjutkan dengan proses running yakni dengan memanfaatkan menu SWAT Simulation.

\section{Kalibrasi dan Validasi}

Pada tahap ini, penggunaan data debit hasil pengukuran lapangan yang diperoleh dari Balai Besar Sungai Sulawesi II dikalibrasi dengan data debit output model SWAT. Nilai NSE (Nash Sutcliffe Coefficient of Efficiency) untuk model data debit ditentukan melalui persamaan berikut ini (Nash and Sutcliffe, 1970).

$$
\begin{aligned}
& N S E=1-\left(\frac{\sum_{i=1}^{n}\left(Q_{O b s, i}-Q_{M o d, i}\right)^{2}}{\sum_{i=1}^{n}\left(Q_{O b s, i}-\bar{Q}_{M o d, i}\right)^{2}}\right) \\
& N S E=1-\left(\frac{(1864.52-1.143)^{2}}{(1864.52-0.09)^{2}}\right. \\
& N S E=1-(-0.15784) \\
& N S E=0.8
\end{aligned}
$$

Efisiensi model NSE dikelompokkan menjadi 3 kelas yaitu "baik" jika NSE $\geq 0,75$, memuaskan jika 0,75 > NSE $\geq 0,36$, dan kurang memuaskan jika NSE $<0,36$ (Moriasi et aldalam
Nursahputra, 2015). Dengan kata lain nilai NSE yang diperoleh termasuk kelas "baik" atau terdapat kemiripan antara pola debit yang dihasilkan model dengan pola debit hasil observasi.

\section{Analisis Output ArcSWAT}

Penentuan kerentanan DAS terhadap kekeringan diperoleh melalui pengolahan output model SWAT dengan penggunaan parameter Soil Water (SW) dalam beberapa persamaan melaui pemanfaatan software ArcGis. Tahap ini secara berurutan menggunakan Persamaan 3 - Persamaan 5, sehingga diperoleh nilai/bobot masing-masing sub DAS.

Salah satu indikator suatu DAS telah mengalami penurunan kualitas dan fungsi DAS adalah defisit pasokan air yang mulai terjadi. Analisis yang digunakan dalam menentukan kerentanan DAS terhadap kekeringan adalah dengan menggunakan Soil Moisture Deficit Index (SMDI) melalui parameter Soil Water $(S W)$. Pada penelitian ini penggunaan output model SWAT melalui ArcSwat, telah mampu menggambarkan kondisi pasokan air pada DAS Limboto. 
Tabel 4. Klasifikasi Kekeringan di Sub DAS Limboto

\begin{tabular}{|c|c|c|c|c|c|}
\hline Sub DAS & Klasifikasi Kekeringan & Bobot & Sub DAS & Klasifikasi Kekeringan & Bobot \\
\hline 1 & Rentan & 2 & 25 & Rentan & 2 \\
\hline 2 & Rentan & 2 & 26 & Rentan & 2 \\
\hline 3 & Rentan & 2 & 27 & Rentan & 2 \\
\hline 4 & Rentan & 2 & 28 & Rentan & 2 \\
\hline 5 & Rentan & 2 & 29 & Rentan & 2 \\
\hline 6 & Rentan & 2 & 30 & Rentan & 2 \\
\hline 7 & Rentan & 2 & 31 & Rentan & 2 \\
\hline 8 & Rentan & 2 & 32 & Rentan & 2 \\
\hline 9 & Rentan & 2 & 33 & Rentan & 2 \\
\hline 10 & Rentan & 2 & 34 & Rentan & 2 \\
\hline 11 & Rentan & 2 & 35 & Rentan & 2 \\
\hline 12 & Rentan & 2 & 36 & Rentan & 2 \\
\hline 13 & Rentan & 2 & 37 & Rentan & 2 \\
\hline 14 & Rentan & 2 & 38 & Rentan & 2 \\
\hline 15 & Rentan & 2 & 39 & Rentan & 2 \\
\hline 16 & Rentan & 2 & 40 & Rentan & 2 \\
\hline 17 & Rentan & 2 & 41 & Rentan & 2 \\
\hline 18 & Rentan & 2 & 42 & Rentan & 2 \\
\hline 19 & Rentan & 2 & 43 & Rentan & 2 \\
\hline 20 & Rentan & 2 & 44 & Rentan & 2 \\
\hline 21 & Rentan & 2 & 45 & Rentan & 2 \\
\hline 22 & Rentan & 2 & 46 & Rentan & 2 \\
\hline 23 & Rentan & 2 & 47 & Rentan & 2 \\
\hline \multirow[t]{2}{*}{24} & Rentan & 2 & 48 & Rentan & 2 \\
\hline & & & 49 & Rentan & 2 \\
\hline
\end{tabular}

Sumber: Hasil Penelitian

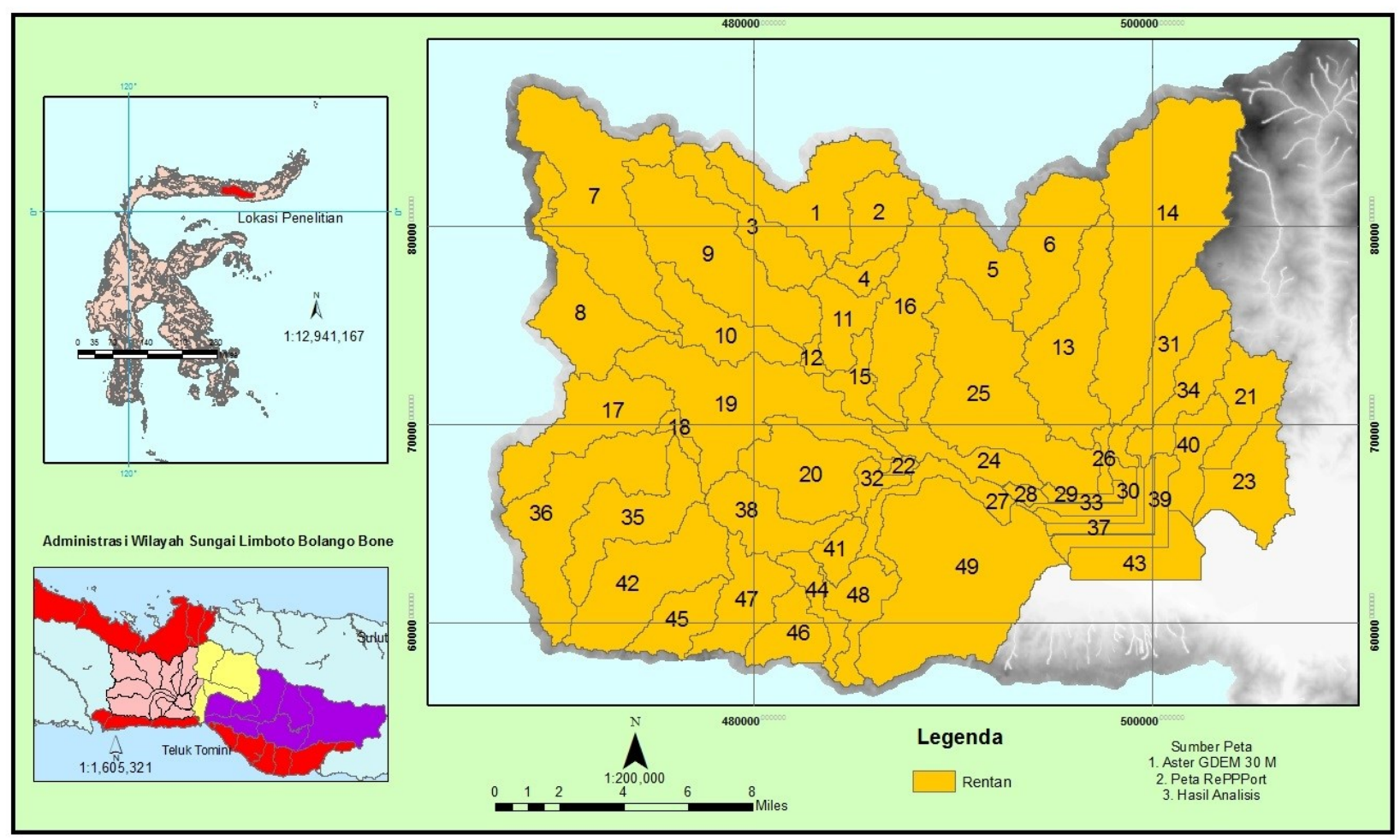

Gambar 2. Peta Tingkat Kerentanan Kekeringan DAS Limboto 
Tabel 5. Rekapitulasi Klasifikasi Kekeringan DAS Limboto

\begin{tabular}{lcccc}
\hline $\begin{array}{c}\text { Nama } \\
\text { DAS }\end{array}$ & $\begin{array}{c}\text { Klasifi- } \\
\text { kasi }\end{array}$ & $\begin{array}{c}\text { Luas } \\
\text { Area } \\
\text { (Ha) }\end{array}$ & $\begin{array}{c}\text { Luas } \\
\text { Area } \\
(\%)\end{array}$ & $\begin{array}{c}\text { Tersebar pada } \\
\text { jumlah Sub DAS }\end{array}$ \\
\hline $\begin{array}{l}\text { Limbo- } \\
\text { to }\end{array}$ & $\begin{array}{l}\text { Rentan } \\
\text { Tidak }\end{array}$ & 86412,6 & 100 & 49 \\
& \begin{tabular}{l} 
Rentan \\
\multicolumn{2}{c}{ Total }
\end{tabular} & - & - & - \\
\hline
\end{tabular}

Sumber: Hasil Penelitian

Menurut (Narasimhan \& Srinivasan, 2005), terdapat 9 klasifikasi indeks SMDI. Klasifikasi ini kemudian dikelompokkan kembali dalam 3 kelas yakni “Tidak Rentan”, "Rentan”, dan "Sangat Rentan”. Dalam DAS Limboto, tidak terdapat ketagori "Sangat Rentan". Artinya rata-rata nilai SD (Soil Deficit) hanya berkisar antara $\leq-1,99$ sampai $\geq 4$. Pada DAS Limboto seluruh sub DAS masuk dalam kategori "Rentan”. Hal ini menunjukkan bahwa DAS Limboto telah mengalami defisit air secara menyuluruh pada seluruh area sub DAS yang ada. Dari hasil Model SWAT, nilai SMDI DAS Limboto pada Bulan Maret, Mei, dan Agustus dalam 10 Tahun adalah $\geq-2$. Nilai ini dalam klasifikasi Narasimhan \& Srinivasan termasuk kategori "Rentan".

Krisis air bisa terjadi secara temporal yakni krisis air pada bulan-bulan tertentu dalam satu tahun. Terutama akibat terjadinya pergeseran iklim serta kemampuan masing-masing DAS dalam menyimpan dan melepas air (Arsyad, 2010). (Sholikhati et al., 2008) menyatakan bahwa kekeringan merupakan salah satu jenis bencana alam yang terjadi secara perlahan, berlangsung lama sampai musim hujan tiba, berdampak sangat luas dan bersifat lintas sektoral (ekonomi, sosial, kesehatan, pendidikan, dll). Guna mencegah kerusakan lingkungan yang tidak hanya menurunkan kualitasnya tapi juga menurunkan kualitas hidup masyarakat setempat, dibutuhkan penanganan efektif dan efisien khususnya pada DAS Limboto yang dalam penelitian ini mempunyai tingkat kerentanan terhadap kekeringan kategori "rentan" yang tersebar dalam 49 sub DAS

\section{Perumusan Arahan Penggunaan Lahan Pada Daerah Aliran Sungai Limboto}

Pengelolaan DAS yang salah satunya adalah penyusunan arahan fungsi pemanfaatan lahan harus dilakukan secara terpadu dan disepakati oleh para pihak (stake holders) sebagai dasar dalam penyusunan rencana pembangunan wilayah (Wuryanta, 2015). Pada DAS Limboto, persentasi lahan yang masih bervegetasi adalah $>50 \%$ sehingga tidak dilakukan perubahan pada lahan terbangun. Dalam penelitian ini, penyusunan arahan penggunaan lahan secara garis besar diuraikan sebagai berikut:

Jika tidak terjadi perbedaan peruntukkan pola ruang dan tutupan lahan maka tutupan lahan/penggunaan lahan yang ada, dirumuskan untuk dipertahankan khususnya pada permukiman dan sawah.

Jika pola ruang adalah hutan lindung tutupan semak belukar, maka penggunaan lahan pada DAS kecil/subDAS diarahkan pada hutan lahan kering sekunder. Namun bila tutupan lahannya adalah pertanian lahan kering ataupun perkebunan maka penggunaan lahan diarahkan pada Agroforestry.

Jika pola ruang adalah kawasan peruntukkan perdesaan dan tutupan lahannya adalah pertanian lahan kering/semak belukar maka penggunaan lahan diarahkan pada Agroforestri. Hal ini berarti dalam penelitian ini terdapat perubahan pola ruang sebagai upaya dalam mengendalikan erosi, banjir, dan kekeringan.

Rumusan arahan pada umumnya disusun berdasarkan perencanaan tata ruang (pola ruang) kabupaten terkait yakni Kabupaten Gorontalo. Arahan ini secara spasial disajikan dalam Gambar 3 .

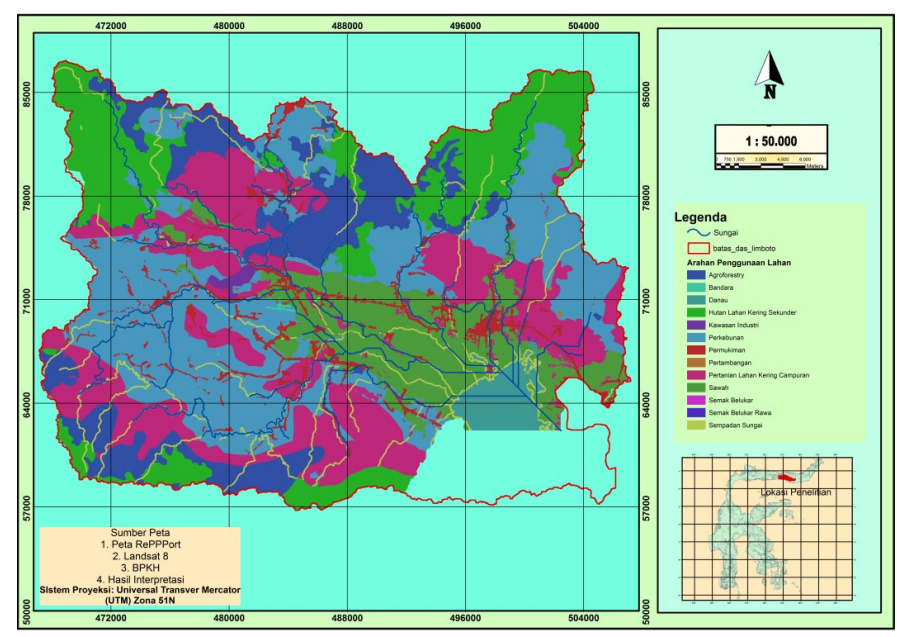

Gambar 3. Peta Arahan Penggunaan Lahan DAS Limboto

\section{Simulasi Arahan Penggunaan Lahan}

Arahan penggunaan lahan yang dihasilkan, pada tahap selanjutnya dilakukan Running atau disimulasikan kembali untuk mengetahui efektivitas arahan yang telah disusun. Dalam tahap ini, peneliti memprioritaskan proses simulasi arahan pada DAS yang termasuk dalam kategori Priorotas I yakni DAS Limboto. Tahapan dalam proses simulasi ini pada umumnya sama dengan proses analisis model Soil and Water Asessment Tools menggunakan software ArcSwat yakni mulai dari proses delineasi hingga pengolahan output ArcSwat. Untuk membandingkan nilai kekeringan yang diperoleh berikut diuraikan rekapitulasi masing-masing nilai pada DAS Limboto sebelum dilakukan simulasi arahan penggunaan lahan.

Rekapitulasi nilai kekeringan berdasarkan hasil simulasi arahan pada DAS Prioritas I. Hasil rekapitulasi ini dapat dilihat pada Tabel 6 . 
Tabel 6. Rekapitulasi Nilai Kekeringan DAS Limboto setelah simulasi arahan

\begin{tabular}{llrr}
\hline DAS Limboto & Klasifikasi & $\begin{array}{r}\text { Luas Area } \\
(\mathrm{Ha})\end{array}$ & $\begin{array}{r}\text { Luas Area } \\
(\%)\end{array}$ \\
\hline \multirow{2}{*}{ Kekeringan } & Rentan & 48821,2 & 56,6 \\
& Tidak Rentan & 37441,7 & 43,37 \\
\hline
\end{tabular}

Sumber: Hasil Penelitian

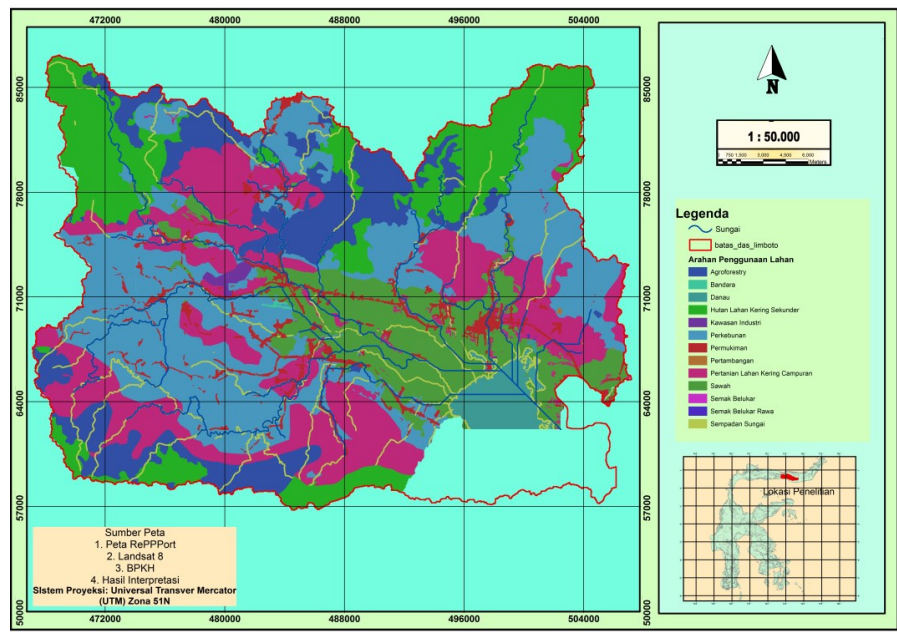

Gambar 4. Klasifikasi Kekeringan DAS Limboto Setelah Simulasi

Dengan membandingkan luas area yang mengalami kekeringan pada sebelum dan setelah dilakukan simulasi/ running arahan penggunaan lahan maka dapat disimpulkan bahwa selisih luas area DAS yang mengalami kerentanan terhadap kekeringan dengan klasifikasi "Rentan", selisih yang diperoleh adalah $37513,1 \mathrm{Ha}$ atau secara persentasi mengalami penurunan sebesar $43,4 \quad$. Kendala utama yang dihadapi dalam perencanaan kekeri ngan di seluruh dunia adalah kurang adanya pengertian $\mathrm{m}$ engenai kekeringan di antara pengambil kebijakan, staf te knik, peneliti, dan masyarakat pada umumnya (Wilhite, 200 0 dalam Adidarma dkk, 2011) untuk itu pemerintah Kabupaten Gorontalo diharapkan mampu meminimalisir kekeringan yang ada melalui pengintegrasian kebijakan antar pengelola DAS.

\section{KESIMPULAN}

Penggunaan lahan eksisiting pada DAS Limboto telah mengindikasikan klasifikasi rentan kekeringan terhadap DAS Limboto, yang tersebar dalam keseluruhan Sub DAS/ DAS Kecil. Hal in kemudian yang mendasari perlu dilakukan simulasi arahan yang telah disusun. Diperoleh penurunan persentasi luas DAS yang mengalami kekeringan, yakni sebesar 43,4 \%. Pada sub DAS yang masih mengalami klasifikasi rentan kekeringan, diperlukan penanganan intensif khususnya pada jenis tanah yang rentan terhadap kekeringan. Misalnya terkait penerapan cara bercocok tanam yang mengedepankan asas konservasi tanah dan air, mengingat penggunaan lahan yang bukan merupakan penyebab utama terjadinya tinggi kekeringan. Berdasarkan hal ini maka diperlukan berbagai penerapan model dalam skenario-skenario dengan penggunaan variabel jenis tanah dan jenis tutupan lahan. Hal ini dapat dilakukan pada penelitian lanjutan yang insyaAllah akan saya teliti lebih lanjut.

\section{UCAPAN TERIMA KASIH}

Jazakumullah khoir DIKTI yang telah mendanai dan UM -Go (Universitas Muhammadiyah Gorontalo) yang telah memfasilitasi.

\section{DAFTAR PUSTAKA}

Adidarma, W. K., Martawati, L., \& Subrata, O. (2011). MODEL MONITORING KEKERINGAN DALAM KERANGKA MANAJEMEN TEMPORAL, 2(2), 113124.

Arnold, J. J., Kiniry, J., Srinivasan, R., Williams, J. R. R., Haney, E. B. B., \& Neitsch, S. L. L. (2011). Soil and water assessment tool: Input/output file documentation version 2009. Texas $A \sim M$ University ..., 662. Diambil dari http://scholar.google.com/scholar? $\mathrm{hl}=\mathrm{en} \& \mathrm{btnG}=$ Search\&q=intitle:SOIL+AND+WATER $+\mathrm{A}+\mathrm{SSESSMENT}+\mathrm{T}+\mathrm{OOL}+\mathrm{I}+\mathrm{NPUT}+$ / $+\mathrm{O}+\mathrm{UTPUT}+\mathrm{F}+\mathrm{ILE}+\mathrm{D}+\mathrm{OCUMENTATION} \# 2 \%$ 5Cnhttp://scholar.google.com/scholar? $\mathrm{hl}=$ en\&btnG=Search\&q=intitle:Soil+and+Water+Ass essment+Tool+Input/Output+File+Docume

Arsyad, S. (2010). Konservasi Tanah dan Air (II). Bogor: IPB. Ferijal, T. (2013). Aplikasi Model SWAT Untuk Mensimulasikan Debit Sub DAS Krueng Meulesong Menggunakan Data Klimatologi Aktual dan Data Klimatologi Hasil Perkiraan. Rona Teknik Pertanian, 6(1).

Kodoatie, R. J. dan R. S. (2010). Tata Ruang Air. Yogyakarta: ANDI.

Meilianda, E. (2017). Analisis Kekeringan Menggunakan Metode Theory of Run di DAS Krueng Aceh, 24(2), 167-172. https://doi.org/10.5614/jts.2017.24.2.8

Narasimhan, B., \& Srinivasan, R. (2005). Development and evaluation of Soil Moisture Deficit Index (SMDI) and Evapotranspiration Deficit Index (ETDI) for agricultural drought monitoring. Agricultural and Forest Meteorology, 133(1-4), 69-88. https:// doi.org/10.1016/j.agrformet.2005.07.012

Sandi Cahyono, Imam Suprayogi, M. F. (2016). Analisis Indeks Kekeringan Menggunakan Metode Thornthwaite Mather Pada Das Siak, (September 2015), 1-15.

Sholikhati, I., Harisuseno, D., Suhartanto, E., Program, M., Teknik, M., \& Universitas, P. (2008). STUDI IDENTIFIKASI INDEKS KEKERINGAN HIDROLOGIS PADA DAERAH ALIRAN SUNGAI ( DAS ) BERBASIS SISTEM INFORMASI GEOGRAFIS ( SIG ).

Tarigan, S., \& Junaidi, E. (2015). ACCURACY OF MAPWINDOW AND SWAT WATERSHED MODEL IN SIMULATING HYDROLOGIC CHARACTERISTICS OF CISADANE WATERSHED , ACCURACY OF MAPWINDOW AND SWAT WATERSHED 
MODEL IN SIMULATING HYDROLOGIC CHARACTERISTICS OF CISADANE WATERSHED , WEST JAVA INDONESIA, (February 2015).

Wuryanta, A. (2015). Arahan Fungsi Pemanfaatan Lahan Berbasis Daerah Aliran Sungai Sebagai Upaya Pelestarian Lingkungan ( Studi Kasus di Sub DAS Samin ds ). In Prosiding Seminar Nasional Innovation in Environmental Management (hal. V-1-V-5). 